\title{
The Scale for Determining The Factors Affecting The Students' Choice of Formal and Distance Education in Secondary School
}

\author{
DOI: $10.26466 /$ opus. 970860
}

\author{
Güler Karaman* - Nurbahar Bora** - Sezer Seven *** \\ *Assist. Prof., Ankara Hacı Bayram Veli University, Faculty of Economics and Administrative Sciences, Ankara/Turkey \\ E-Mail: karaman.guler@hbv.edu.tr ORCID: 0000-0001-5713-6759 \\ ** Ph.d. Student, Atatürk University, Institute of Social Sciences, Erzurum/Turkey \\ E- Mail: nurbaharbora@gmail.com ORCID: 0000-0001-9286-0216 \\ *** Research Assist., Tarsus University, Faculty of Economics and Administrative Sciences, Mersin/Turkey \\ E- Mail: sezerseven@tarsus.edu.tr \\ ORCID: 0000-0003-1035-1210
}

\begin{abstract}
The purpose of this study is to develop a scale for determining the factors that will affect students' choice of formal education and distance education in secondary education. The study composed of two parts. While in the first part, the scale development steps were carried out to develop the scale, in the second part, the scale was conducted. The sample of the scale development part is composed of 100 women and 116 men, totally 216 volunteer participants, studying at Anatolian High School, Science High School and Vocational High School in a metropolis, during the first semester of 2020-2021. The data were collected through data collection form consisting of item pool. With SPSS 24.0 package program, the analysis of the data was carried out. Factor analysis was applied for the validity and reliability of the developed scale. As a result of the analysis, a scale consisting of 8 factors and 30 items was developed, 4 factors related to formal education and 4 other factors related to distance education. This scale, which will guide formal education and distance education, is very important in terms of guiding the future studies. In the second part of the study, the developed scale was conducted to 120 volunteers (55 females and 65 males) attending to Anatolian High School, Science High School or Vocational High School in the 2020-2021 fall semester participated in the study. The data obtained in the study were collected with the help of printed and digital forms. Within the scope of the study, 2 research questions were determined. With the SPSS 24.0 package program, the data were analyzed by One-Way ANOVA tests by looking at the skewness and kurtosis values of the data. As a result of the study, it was concluded that there was no significant difference between the preference of formal education and distance education of the students in the secondary education level and the school type variable. However, it is also concluded that there was a significant difference between formal education and distance education preference of secondary education level students and the time they spent on the internet.
\end{abstract}

Key Words: $\quad$ Formal Education, Distance Education, Scale Development, Secondary School, Student' Choice. 


\section{Ortaöğretim Kademesindeki Öğrencilerin Örgün Öğretim ve Uzaktan Eğitimi Seçmelerini Etkileyecek Unsurların Belirlenmesi Ölçeği}

Öz

$B u$ çalışmanın amacl, ortaöğretim kademesindeki öğrencilerin örgün öğretim ve uzaktan eğitimi seçmelerini etkileyecek unsurların belirlenmesine yönelik bir ölçek geliştirmedir. Ölçek çalışmasının örneklemini, 2019-2020 yllnın birinci döneminde bir büyükşehirde MEB'e bağh devlet ve özel okullarda Anadolu Lisesi, Fen Lisesi ve Meslek Liselerinde öğrenim gören, 100' ü kadın, 116'sı erkek, toplam 216 gönüllü katılımoı oluşturmaktadır. Çalışmada nicel analiz yöntemi kullanılarak, veriler anket yoluyla toplanmıştır. SPSS 24.0 paket programı ile verilerin analiz işlemleri gerçekleşmiştir. Geliştirilen ölçeğin geçerliliği ve güvenilirliği için faktör analizi uygulanmıştır. Analizler neticesinde 4 faktör örgün öğretimle, diğer 4 faktör ise uzaktan eğitimle ilgili olmak üzere toplam 8 faktör ve 30 maddeden oluşan ölçek geliştirilmiştir. Örgün öğretim ve uzaktan eğitime yön verecek olan bu ölçek bundan sonra yapılacak çalışmalara yol göstermesi bakımından oldukça önemlidir. Ölçeğin uygulanması için de, 2019-2020 yılının birinci döneminde bir büyükşehirde MEB'e bağh devlet ve özel okullarda Anadolu Lisesi, Fen Lisesi ve Meslek Lisesinde öğrenim gören, 55'i kadın, 65' i erkek, 120 gönüllü katılımo çalışmada yer almıştır. Çalışmada elde edilen veriler, kâ̆ğı ve dijital anket yardımıyla toplanmıştır. Çalışma kapsamında 2 araştırma sorusu belirlenmiştir. SPSS 24.0 paket programı ile verilerin çarpıklık ve basıklık değerlerine bakılarak One-Way Anova testleri ile verilerin analiz sağlanmıştır. Çalışma sonucunda, ortaöğretim kademesindeki öğrencilerin örgün öğretim ve uzaktan eğitimi tercih etme durumları ile okul türü değişkeni arasindaki anlamlı bir farklılı̆̆ın olmadığ sonucuna, ortaöğretim kademesindeki öğrencilerin örgün öğretim ve uzaktan eğitimi tercih etme durumlar ile internette geçirmiş oldukları vakit arasında anlamlı bir farklılı̆̆ın olduğu sonucuna ulaşılmıştır.

Anahtar Kelimeler: Örgün Öğretim, Uzaktan Ĕ̆itim, Ölçek Geliştirme, Orta Öğretim, Öğrenci Tercihi. 


\section{Introduction}

The issue of education, which has been continuing since the day of human existence, has gained more importance in the last century and has been considered the backbone of a nation by many intellectuals of history. In recent years, many countries in the world want to create the best system in education and increase the number of qualified people to the maximum level according to the population ratio. Thus, quite a lot of scientific studies are carried out and pilot schemes are performed. The majority of the studies are done for students studying in formal education. Therefore, improvements are more limited for distance education students. Distance education first started in England and continued with the development of technological facilities such as letters, television, telephone and video (Gülbahar, 2009). In fact, nowadays the direction of acceleration is rapidly shifting to distance education and people could take the lessons of an expert through distance education whenever they want. Since distance education provides space and time flexibility, people turn to this type of education, and this increase accelerates every day. However, disadvantages of distance education are that students cannot access the tools to be used in distance education, the technological environment is not arranged for distance education, or the personnel who will use this technology do not have sufficient technological knowledge. In formal education, face-to-face education activities are ensured to continue teacher-centered within a certain plan by adhering to a place. The best part of formal education over distance education is that it helps students interact with each other and contribute to their socialization. The fact that a scale development study has not been put forward as a whole to determine which factors the secondary education students take into consideration when choosing both distance education and formal education reveals the reason for this study. Some current studies examining and investigating some aspects of the issue in the literature compiled in the following paragraphs.

Considering the effects of formal education on students as the problem situation, Uslu (2018) developed a scale that measures the relationship between physical, social and educational factors and mental states in the learning environment of students, and examined the effects of formal education on students. In Yürekli (2018), which exemplifies the expectations of stu- 
dents about formal education preference, it is tried to determine students' views on the scientific, social, physical and cultural facilities that impact on students' university choices. In their study, Muilenburg and Berge (2001) tried to determine the structures that prevent distance education, and the categories that prevent distance education are examined in three parts as situational, institutional and educational. Street (2010) examined the student's decision on quit or continue in distance education by dividing them into internal and external factors, in addition to group the continuance of distance education according to behavior, course, environmental and personal factors. In the study by Galusha (1998) focusing on how to prevent obstacles in distance education, helped to closely examine the internal problems in distance education, and suggested that technological developments would be helpful to tackle with those obstacles. Baturay and Bay's (2009) examined the reasons for students to choose distance education, their expectations and their goals after graduation. In Ateş (2019), "Life Satisfaction Scale for High School Students" was developed to determine the life satisfaction of high school students. It has been concluded that the developed scale is valid and reliable in order to determine the life satisfaction levels of high school students. Ağır (2007) conducted the "Distance Education Attitude Scale" to determine teachers' attitudes towards distance education according to their gender, institution, professional seniority, education level, study field, and whether they have information about distance education or not. Accordingly, it is concluded that although the teachers' attitude levels towards distance education are close to the middle value, it is found to be positive. This shows that distance education is accepted by teachers as a type of education. Therefore, with the increasing interest in distance education, studies have been carried out to identify and remove the obstacles to this type of education.

According to the literature review, it is plausible to infer that previously conducted studies do not address issue of determining the factors affecting the students' choice of formal and distance education as a whole. In this study, it is aimed to deal with the issue from various aspects. To do so, in the scope of this paper, a scale development study has been carried out to examine students' preference on distance education and formal education, and their expectations. 


\section{Objective and Importance of The Study}

In this study, it was aimed to develop a scale for determining the reasons for secondary education students to prefer distance education and formal education. In the line with this purpose, in this two parts study, a scale was first developed, and then data collection via this scale and analyzed. In this context, the research questions of the study are presented in two parts.

During the development of the scale, the study was conducted by seeking answers to the following research questions.

1. What are the factors that affect the preference of the students attending different high school types on distance education or formal education?

2. What are the elements that will affect the students of different high school types to choose distance education or formal education?

The scale was developed a result of the studies in the first part of the research and conducted to the students studying in different types of high schools in state and private institutions affiliated to the Ministry of National Education. During the application of the scale, the study was conducted by seeking answers to the following research questions.

1. Is there a significant difference between preference of secondary education students on formal or distance education and the school type variable?

2. Is there a significant difference between secondary education students' preference for formal and distance education and the time they spend on the internet?

\section{Method}

Prior to the data collection process of this study, ethical approval was obtained from the university ethical committee so that there was no ethical or scientific objection. With the voluntary consent of the participants, data collection process was carried out online by the authors between February and March in the spring semester of the 2020-2021 academic year.

Quantitative research method was used in this study aimed at determining the attitudes and opinions of secondary education students towards distance education and formal education. In this study, data collected via 
printed and digital data collection form. In this section, explanations about the population and sample of the research, data collection tools, scale development process, data analysis, the role of researchers, validity and reliability are presented.

\section{Research Population and Sampling}

For the scale development part of the study, the sample consists of students studying in public and private schools (Anatolian, Science and Vocational High Schools) in secondary education in a metropolitan city. In fall semester of 2020-2021, data were collected from 216 participants, 100 of whom were women and 116 were men. The students attending the Anatolian High School participated the most in the study. In the second part of the study, the developed scale was conducted to 120 volunteers ( 55 females and 65 males) attending to Anatolian High School, Science High School or Vocational High School in the 2020-2021 fall semester participated in the study.

\section{Data Collection Tools}

In this scale development study, an item pool was created by taking the literature review and expert opinion. The developed scale consists of two parts. The first part consists of 13 independent variables including the demographic information of the participants. These are; gender, school type, area, education level of the mother, the education level of the father, the monthly income of the family, the way of education in higher education, the status of taking courses about distance education before, the status of providing internet connection in distance education, preference for technological devices in distance education, the daily time spent on the internet, social media application where most time is spent and the status of having a personal computer. In the second part, the items of "Scale for Measuring the Perception and Attitudes of Secondary Education Students " are included.

\section{Scale development process}

In this study, the scale development process proposed by Karaman (2015) was employed (Figure 1). 
During the literature review phase for the scale development process, "scale development in distance education", "scale development in formal education", "university preferences", "attitude towards distance education", "attitude towards formal education", "barrier to distance learning" and "drop-out distance learning" statements have been used as keywords for searching in order to create item pool. "Google Scholar", "National Thesis Center", "Web of Science" and "YÖK Academic" are the search engines used for the literature review.

As a result of the literature review, an item pool consisting of 148 items was compiled. These items were simplified with expert opinion to 67 items in the first phase, and in the second phase, an expert interview was conducted to determine that 13 items included each other, so these items were removed from the pool and reduced to 54 items, which is the last number of the item pool. Moreover, incomplete and incoherent statements in items were corrected and the items were finalized. After the questionnaire was entitled, it was submitted to the opinion of the language expert, and necessary arrangements were made.

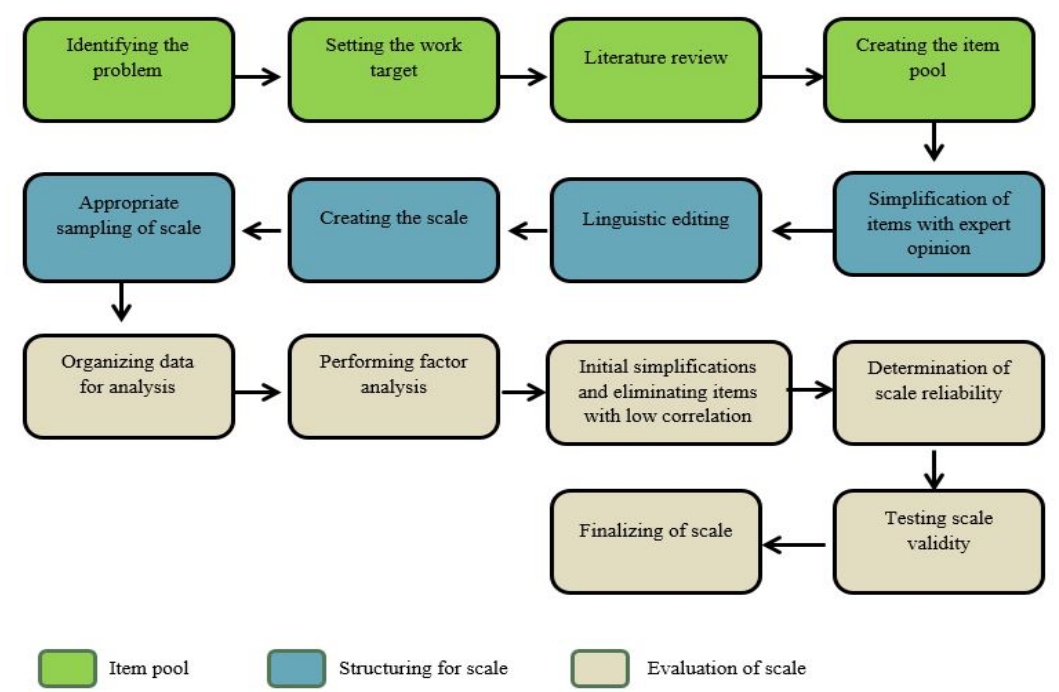

Figure 1. Scale Development Phases (Karaman, 2015) 
After consultation to experts regarding context, and proofreading conducted by linguists, the scale form was formatted. In the first part of the scale, 13 items about demographic information are included. The form was prepared according to the 5 -point Likert scale $(1=$ Strongly Disagree, $2=$ Agree, $3=$ Undecided, $4=$ Agree, $5=$ Strongly Agree) with 54 items. The scale items are randomly ordered, and 5 of them are negative and 49 are positive statement.

The developed scale was conducted by the researchers to 230 participants in total. While 130 forms were delivered digitally, 86 forms delivered as printed. The evaluations were made by the researchers, the application of the participants who made the same choice more than once were excluded, and the data collected form 216 participants was evaluated.

In terms of the validity and reliability of the scale, in addition to literature review and expert opinions, some statistical analysis were carried out. The reliability of the scale calculated with both Cronbach Alpha internal consistency and Spearman Brown split-half reliability coefficients(Karaman, 2015). The study was validated by using item and factor analysis. As a result of the statistical analysis, it was concluded that the data have normal distribution and the developed scale could be used safely. As a result of statistical analysis, the scale form, consisting of 13 demographic and 54 Likert items, was reduced to 30 Likert-type items, and the scale development process was finalized (ANNEX 1).

\section{Data Analysis}

In this study, both the data collected for scale development and the data collected via the developed scale were analyzed.

\section{Analysis of Quantitative Data}

Firstly, the data collected for scale development was analyzed. The 5 items that were negative were made reverse coded and the analysis process was initiated. The data obtained from the participants were analyzed statistically through the SPSS 24.0 package program. Validity and reliability procedures of the developed scale were performed with the data collected from 230 participants. 
Kaiser-Meyer-Olkin (KMO) coefficient and Bartlett Sphericity test were employed to determine the suitability of the data to factor analysis (Bayram, 2004; Büyüköztürk, 2005). Item interaction correlation was calculated with Spearman Brown split half test correlation and Cronbach alpha internal consistency coefficient. After determining the suitability of the data to factor analysis, exploratory factor analysis was used to indicate the construct validity and factor structure of the developed scale. The analysis process was accomplished by examining the common factor variance of the factors on the variable, the factor loads of the items, the explained variance ratios and the line graph. The factor loads of the items were determined to be at least 0.40 .

Secondly, the data which is collected from 120 participants via the developed "Scale for Determining the Factors Affecting the Choice of Formal Education and Distance Education of Secondary Education Students" was analyzed. Data analysis was carried out with SPSS 24.0 package program. Based on the research questions, the analysis procedures were completed by performing the One-Way ANOVA test to determine the significant difference between the averages of more than two independent groups (Büyüköztürk, 2014).

In terms of role of the researchers, they have reached many publications on distance education and formal education by reviewing the literature. They created items pool according to this review. They also carried out the procedures of adding, deleting and editing the items according to expert opinion. Moreover, they made arrangements on the scale and created the questionnaire form in digital environment and presented it to the participants. Furthermore, the validity and reliability of the developed scale were analyzed by the researchers. In addition they reported the findings in addition to other formalities.

\section{Findings}

\section{Factors Affecting Students' Choosing Distance Education or Formal Edu- cation in Different Types of High Schools}

In this section, in the light of the data obtained from the participants, the items formed according to the 5-point Likert scale were grouped by consid- 
ering their meaning and functions, and two groups named as "Formal Education" and "Distance Education" were created. The grouping process was terminated by dividing "Formal Education" into sub-titles such as "Effect of Formal Education on Students", "Reasons for Choice of Formal Education", "Advantages of Formal Education for Students" and "Students' Preparing for Exams". The grouping process was terminated by dividing "Distance Education" into sub-titles as "The Effect of Distance Education on the Student", "The Reasons for the Choice of Distance Education", "The Advantages of Distance Education for Students" and "Perception of Distance Education of Students".

\section{Data Suitability for Factor Analysis}

The suitability of the scale data obtained through the questionnaire to factor analysis was ensured by the Kaiser-Meyer-Olkin (KMO) coefficient and the Barlett Sphericity test (Bayram, 2004; Büyüköztürk, 2005). KMO statistics take value between $0-1$. The significance of the data was found by applying factor analysis (KMO coefficient $84.5 \%(0.845>0.60)$ and the significance status for Barlett test $=0.000 \mathrm{p}<0.001$. It was determined that the KMO coefficient was at a high level. Therefore, it is suitable for factor analysis (Hutcheson \& Sofroniou, 1999). According to the criteria determined as a result of the analysis, the factor loads were distributed to more than one factor with a coefficient below 0.40 , and items with a difference of less than 0.10 were excluded from the analysis. In the study of Büyüköztürk (2006), it is stated that if the items have a high load value in a single factor and a low load value in other factors, the analysis processes should be carried out considering the difference between these two high load values at least 0.10 . The items considered to be excluded from the scale are shown in Table 1 below.

Table 1. Survey Questions Based on Explanatory Factor Analysis

\begin{tabular}{ll}
\hline Phases & Questions Eliminated \\
\hline $\mathbf{1}$ & $49,10,13,46,6$ \\
$\mathbf{2}$ & $8,53,26,35,51,17$ \\
$\mathbf{3}$ & $50,27,5,44,19,7$ \\
$\mathbf{4}$ & $21,39,40$ \\
$\mathbf{5}$ & 18 \\
$\mathbf{6}$ & 11,12 \\
\hline
\end{tabular}


The study started with 54 5-point Likert items, after elimination, it was reduced and the scale was composed of 30 Likert-type items and was formed to be used. Table 2 shows the rates of KMO and Barlett test results calculated with 54 items and 30 items of the scale.

\section{Table 2. KMO and Bartlett's Test Values}

\begin{tabular}{ll}
\hline Obtained with 54 items & \\
\hline Kaiser-Meyer-Olkin Measure of Sampling Adequacy. & 0,833 \\
Bartlett's Test of Sphericity Approx. Chi-Square & 4782,192 \\
Df & 1431 \\
Sig. &, 000 \\
Obtained with 30 items & \\
Kaiser-Meyer-Olkin Measure of Sampling Adequacy. & 0,845 \\
Bartlett's Test of Sphericity Approx. Chi-Square & 2096,113 \\
Df & 435 \\
Sig. &, 000 \\
\hline
\end{tabular}

While there are 54 items in the scale according to Table 2, it is seen that the $\mathrm{KMO}$ value calculated as $83.3 \%$, then it increases to $84.5 \%$ when it is calculated with 30 items. Reliability rates of the scale with Cronbach Alpha and Spearman Brown tests were determined.

\section{Findings Regarding Likert Type Items}

The findings of the Likert type items of the scale are shown in Table 3

Table 3. Findings of the Scale Items: Total Variance Explained by Factor Analysis

\begin{tabular}{|c|c|c|c|c|c|c|c|}
\hline \multicolumn{3}{|c|}{ Items Eigenvalues } & \multicolumn{5}{|c|}{ Rotation sums of Squared Loadings } \\
\hline \multirow[b]{2}{*}{ Total } & \multicolumn{2}{|c|}{ Variance } & \multicolumn{2}{|c|}{ Variance } & \multicolumn{3}{|c|}{ Variance } \\
\hline & $\%$ & Cumulative \% & Total $\%$ & Cumulative $\%$ & Total & $\%$ & Cumulative \% \\
\hline 17,39 & 924,662 & 24,662 & $7,39924,662$ & 24,662 & 4,253 & 14,176 & 14,176 \\
\hline 22,17 & 17,238 & 31,900 & $2,1717,238$ & 31,900 & 2,305 & 7,682 & 21,858 \\
\hline 31,77 & 55,921 & 37,821 & $1,7765,921$ & 37,821 & 2,227 & 7,422 & 29,280 \\
\hline 41,58 & 5,282 & 43,103 & $1,5855,282$ & 43,103 & 2,092 & 6,972 & 36,253 \\
\hline 51,41 & 4,717 & 47,821 & $1,4154,717$ & 47,821 & 2,076 & 6,921 & 43,174 \\
\hline 61,35 & 4,505 & 52,325 & $1,3514,505$ & 52,325 & 2,030 & 6,768 & 49,942 \\
\hline $7 \quad 1,24$ & 74,155 & 56,481 & $1,2474,155$ & 56,481 & 1,728 & 5,759 & 55,701 \\
\hline 81,09 & 23,639 & 60,119 & $1,0923,639$ & 60,119 & 1,325 & 4,418 & 60,119 \\
\hline 969 & 3,229 & 63,348 & & & & & \\
\hline 10,855 & 2,849 & 66,197 & & & & & \\
\hline 11,832 & 2,774 & 68,971 & & & & & \\
\hline
\end{tabular}


The factor load values of the items is shown in Table 4. The scale form was visually arranged by examining the contents of the items and the relationships of the factors. In this direction, the scale items were grouped under two main headings in line with the relationship levels of the factors. These are "Formal Education" and "Distance Education". The items under the first (the effect of formal education on the student), the second (the reasons for the preference of formal education), the fifth (the advantages of formal education for students) and the seventh factors (the students' preparation for exams) are grouped under "Formal Education". Items under the third (Reasons for preference of distance education), the fourth (effect of distance education on students), the sixth (advantages of distance education for students) and the eighth factors (students' perception of distance education) are grouped under "Distance Education". The line graph belonging to the factors is shown in Figure 2 and it is observed that the line graph starts to lose its slope significantly starting from the eighth factor. For this reason, the factor number is determined as eight.

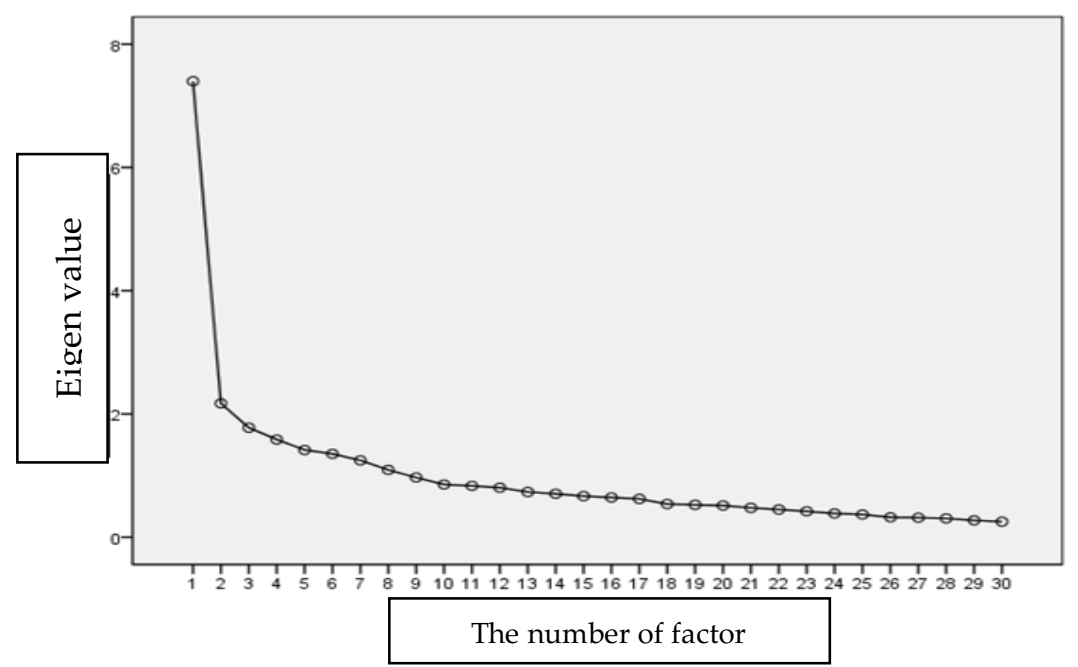

Figure 2. Line chart belonging to the factors

The factor names are summarized in Table 5. 
The Scale for Determining The Factors Affecting The Students' Choice of Formal and Distance Education in Secondary School

Table 5. Naming the Factors

\begin{tabular}{ll}
\hline Factor No & Factor Titles \\
\hline $\mathbf{1}$ & The Effect of Formal Education on Students \\
$\mathbf{2}$ & Reasons for Choosing Formal Education \\
$\mathbf{3}$ & Reasons for Choosing Distance Education \\
$\mathbf{4}$ & The Effect of Distance Education on Students \\
$\mathbf{5}$ & Advantages of Formal Education for Students \\
$\mathbf{6}$ & Advantages of Distance Education for Students \\
$\mathbf{7}$ & Students' Preparation for Exams \\
$\mathbf{8}$ & Students' Perception of Distance Education \\
\hline
\end{tabular}

\section{Factors Affecting the Choice of Distance Education or Formal Education of Students Studying in Different Types of High Schools}

Survey questions obtained as a result of the literature review and expert opinion were grouped by factor analysis and named considering the relevance of meaning. Table 6 shows the items and names of each factor.

Table 6. Indicators to Determine the Factors Affecting Students' Choices of Formal Education and Distance Education

FORMAL EDUCATION

The Effect of Formal Education on Students

1. Practical lessons are taught more effectively in formal education.

2. Formal education enables students to socialize.

3. Group work in classroom activities ensures effective learning.

4. At school, more is learned than what is learned at home.

5. Scholarships and internship opportunities are offered to students in formal education.

6. The effect of the teacher in formal education is more than that of distance education.

7. Face to face interaction is much in formal education.

8. Spending my student period in a different city may lead me to prefer formal education.

Reasons for Choosing Formal Education

9. The food facilities provided by the school are important to me.

10. The reason why I prefer formal education is that schools have spring festivals.

11. Using laboratory materials is important for me to choose formal education.

12. I prefer formal education because I want to study in a department that is not included in distance education.

Advantages of Formal Education for Students

13. I would like to learn about other students' success in exams.

14. Students sitting in the front row are more successful.

15. Homework control affects learning.

16. I write down every word that comes out of the teacher's mouth.

Students' Preparation for Exams

17. I study enough to pass lessons.

18. I prepare for the exams at the last minute.

DISTANCE LEARNING 
The Effect of Distance Education on Students

19. According to distance education, the low number of students in formal education reduces communication problems.

20. Taking some courses in formal education prevents problems in terms of practice.

21. When I choose distance education, this may lead me to prefer formal education due to the insufficient attention of the academic staff and the concern of inadequate technical support.

\begin{tabular}{l}
\hline Reasons for Choosing Distance Education \\
22. Older people prefer to benefit from distance education activities. \\
23. People who have to work have the opportunity to complete their learning process through distance \\
education. \\
24. Distance education activities are suitable for those who have time and space constraints. \\
25. Individuals having responsibilities for the care of their families prefer distance education. \\
\hline Advantages of Distance Education for Students \\
\hline 26. With distance education, it is easy to meet the learning needs of disabled students. \\
27. I can take lessons from famous academicians through distance education. \\
28. Housewives often participate in distance education activities. \\
\hline Distance Education Perception of Students \\
\hline 29. Writing distance education in the diploma in job applications prevents recruitment. \\
30. Later on, a marriage might lead me to choose distance education.
\end{tabular}

\section{Reliability of the Scale}

The reliability of the developed scale was calculated with both Cronbach Alpha and Spearman Brown tests. The Cronbach Alpha internal consistency coefficient of the scale was calculated and found to be 0.817 for 30 Likert items. The Spearman Brown split half-test correlation of the test was found to be 0.740 . Therefore, it can be concluded that the scale could be used safely to determine the attitudes of secondary education students towards choosing formal and distance education.

\section{Findings of the Applied Study}

The data collected from 120 participants via developed scale was analyzed. The reliability of the data was calculated with the Cronbach Alpha method and found to be 0.869 , which means that it is reliable. According to Tabachnick and Fidell (2013), the Skewness and Kurtosis results should be between -1.5 and +1.5 for normal distribution of the data. For normal distribution test, while the skewness was found to be 0.441 and kurtosis was found to be 0.272 for formal education, skewness was found to be -0.510 and kurtosis was found to be -0.749 for distance education. This indicates that the data 
have normal distribution. Therefore, further analysis can be conducted to answer research question.

In order to answer the question "Is there a significant difference between secondary education students' preference for formal and distance education and school type?", this sentence should be referenced for Levene Test.

Table 7. Levene Results Regarding the Relationship between Students' Preferences for Formal Education and Distance Education and School Type Variable

\begin{tabular}{lllll}
\hline & Levene & $d f 1$ & $d f 2$ & Sig. \\
\hline Formal Education & 0,352 & 2 & 117 & 0,704 \\
Distance Education & 3,003 & 2 & 117 & 0,053 \\
\hline
\end{tabular}

Since the significant values are greater than 0.05 , the variances of the groups are homogeneous (Kalayc1, 2014).

Then, One-Way ANOVA test was conducted on the data and results are shown in Table 8.

Table 8. One-Way ANOVA Test Result Regarding the Relationship Between Students' Preferences for Formal Education and Distance Education and School Type Variable

\begin{tabular}{|c|c|c|c|c|}
\hline Dimension & School Type & $N X S S$ & $P$ & \\
\hline & $\begin{array}{l}\text { Anatolian High School, Science High School Vocational } \\
\text { High School Total }\end{array}$ & $853,2580,639$ & 0,504 & 0,605 \\
\hline & Anatolian High School, Science High School Vocational & & & \\
\hline Formal & High School & $83,2500,707$ & & \\
\hline \multicolumn{5}{|c|}{ EducationTotal } \\
\hline & $\begin{array}{l}\text { Anatolian High School, Science High School Vocational } \\
\text { High School }\end{array}$ & $273,1160,640$ & & \\
\hline & Total & $1203,2260,640$ & & \\
\hline & Anatolian High School & $853,3640,704$ & 0,805 & 0,450 \\
\hline Distance & Science High School & $83,5000,534$ & & \\
\hline Education & $n$ Vocational High School & $273,2080,587$ & & \\
\hline & Total & $1203,3380,669$ & & \\
\hline
\end{tabular}

In Table 8, when the school type variable levels of students' preference for formal education and distance education are compared, it is seen that the highest average belongs to science high school $(X=3,500)$ in terms of distance education preferences. On the other hand, for formal education preferences, the lowest average belongs to Vocational High School students $(x=$ $3,116)$. According to the results of the One-Way Anova test, there is no sig- 
nificant difference between formal education ( $p>0.605)$ and distance education ( $p>450)$ for the school type variable.

In order to answer the question "Is there a significant difference between secondary education students' preference for formal and distance education and the time they spend on the internet?", Levene Test is conducted and results are shown in Table 9.

Table 9. Levene Result of the relationship between students' preference for formal and distance education and their time spent on the Internet

\begin{tabular}{lllll}
\hline & Levene & $d f 1$ & $d f 2$ & Sig. \\
\hline $1^{\text {st }}$ factor average & 3,107 & 4 & 115 & 0,018 \\
$2^{\text {nd }}$ factor average & 0,869 & 4 & 115 & 0,485 \\
$3^{\text {rd }}$ factor average & 1,330 & 4 & 115 & 0,263 \\
$4^{\text {th }}$ factor average & 1,903 & 4 & 115 & 0,115 \\
$5^{\text {th }}$ factor average & 3,663 & 4 & 115 & 0,008 \\
$6^{\text {th }}$ factor average & 2,444 & 4 & 115 & 0,051 \\
$7^{\text {th }}$ factor average & 1,776 & 4 & 115 & 0,138 \\
$8^{\text {th }}$ factor average & 0,542 & 4 & 115 & 0,705 \\
\hline
\end{tabular}

In Table 9, it has been revealed that the variances of the groups are homogeneous since the "sig" value of the $2 \mathrm{nd}$, 3rd, 4th, 6th, 7th and 8th factor averages in the formal education and distance education categories ( $p>.05)$. This means that, results for those factors should be interpreted according to Tukey test which is one of the Post Hoc tests. Post Hoc test is used to show which groups this difference originates from when a significant difference is found between groups as a result of variance analysis (Kalaycl, 2014, p.135). It is understood that the variances of the groups are not homogeneous due to the "sig" value of the 1st and 5th factor averages less than 0.05 , therefore, it is understood that the Tamhane's T2 test, which is also a Post Hoc test, should be used to interpret the results for those two factors (Kalaycl, 2014, p.145). One-Way Anova test results are shown in Table 10. 
The Scale for Determining The Factors Affecting The Students' Choice of Formal and Distance Education in Secondary School

Table 10. The Relationship Between Students' Preferences for Formal and Distance Education and the Time They Spend on the Internet

\begin{tabular}{|c|c|c|c|c|c|c|}
\hline Dimension & Time Spent & $N$ & $X$ & SS & $F$ & $P$ \\
\hline \multirow{7}{*}{$1^{\text {st }}$ factor } & 0-1 hour & 32 & 3,78 & 1,039 & 0,401 & 0,807 \\
\hline & 1-2 hours & 38 & 3,95 & 0,695 & & \\
\hline & 2-3 hours & 27 & 3,93 & 0,730 & & \\
\hline & 3-4 hours & 13 & 4,00 & 0,000 & & \\
\hline & 5 hours and more & 10 & 3,70 & 1,059 & & \\
\hline & Total & 120 & 3,88 & 0,801 & & \\
\hline & 0-1 hour & 32 & 3,22 & 0,975 & 0,966 & 0,429 \\
\hline \multirow{4}{*}{$2^{\text {nd }}$ factor } & 1-2 hours & 38 & 3,50 & 0,893 & & \\
\hline & $2-3$ hours & 27 & 3,44 & 0,847 & & \\
\hline & 3-4 hours & 13 & 3,08 & 0,760 & & \\
\hline & 5 hours and more & 10 & 3,10 & 1,101 & & \\
\hline \multirow{4}{*}{$3^{\text {nd }}$ factor } & Total & 120 & 3,33 & 0,911 & & \\
\hline & 0-1 hour & 32 & 2,81 & 0,965 & 4,022 & $0,004^{*}$ \\
\hline & 1-2 hour & 38 & 3,21 & 0,990 & & \\
\hline & 2-3 hour & 27 & 2,43 & 0,705 & & \\
\hline \multirow{8}{*}{$4^{\text {th }}$ factor } & 3-4 hours & 13 & 3,00 & 0,707 & & \\
\hline & 5 hours and more & 10 & 2,30 & 0,948 & & \\
\hline & Total & 120 & 2,83 & 0,939 & & \\
\hline & 0-1 hour & 32 & 2,88 & 1,289 & 3,220 & $0,015^{*}$ \\
\hline & 1-2 hours & 38 & 2,55 & 1,132 & & \\
\hline & 2-3 hours & 27 & 2,81 & 1,075 & & \\
\hline & 3-4 hours & 13 & 3,46 & 1,198 & & \\
\hline & 5 hours and more & 10 & 3,80 & 0,789 & & \\
\hline \multirow{3}{*}{$5^{\text {th }}$ factor } & Total & 120 & 2,90 & 1,191 & & \\
\hline & 0-1 hour & 32 & 3,46 & 0,841 & 3,082 & $0,019^{*}$ \\
\hline & 1-2 hours & 38 & 3,42 & 0,919 & & \\
\hline \multirow{9}{*}{$6^{\text {th }}$ factor } & 2-3 hours & 27 & 3,38 & 0,880 & & \\
\hline & $3-4$ hours & 13 & 3,84 & 0,375 & & \\
\hline & 5 hours and more & 10 & 2,60 & 1,074 & & \\
\hline & Total & 120 & 3,40 & 0,891 & & \\
\hline & 0-1 hour & 32 & 3,81 & 1,060 & 1,244 & 0,296 \\
\hline & $1-2$ hours & 38 & 3,65 & 0,745 & & \\
\hline & 2-3 hours & 27 & 3,64 & 0,806 & & \\
\hline & 3-4 hours & 13 & 3,92 & 0,493 & & \\
\hline & 5 hours and more & 10 & 3,20 & 1,032 & & \\
\hline \multirow{4}{*}{$7^{\text {th }}$ factor } & Total & 120 & 3,68 & 0,862 & & \\
\hline & 0-1 hour & 32 & 3,34 & 1,065 & 0,786 & 0,536 \\
\hline & 1-2 hours & 38 & 3,57 & 0,948 & & \\
\hline & 2-3 hours & 27 & 3,39 & 0,704 & & \\
\hline \multirow{9}{*}{$8^{\text {th }}$ factor } & 3-4 hours & 13 & 3,76 & 0,725 & & \\
\hline & 5 hours and more & 10 & 3,30 & 0,823 & & \\
\hline & Total & 120 & 3,47 & 0,899 & & \\
\hline & 0-1 hour & 32 & 2,75 & 0,880 & 0,115 & 0,977 \\
\hline & 1-2 hours & 38 & 2,74 & 1,032 & & \\
\hline & 2-3 hours & 27 & 2,81 & 1,039 & & \\
\hline & 3-4 hours & 13 & 2,92 & 1,038 & & \\
\hline & 5 hours and more & 10 & 2,70 & 1,059 & & \\
\hline & Total & 120 & 2,78 & 0,983 & & \\
\hline
\end{tabular}

${ }^{*} P<0,05$ 
In Table 10, when the levels of the time spent on the internet compared with students' preference for formal and distance education, it is seen that the highest average belongs to the 1st factor dimension with 3-4 hours $(X=$ $4.00)$, the lowest average belongs to 3rd factor dimension with 5 hours and over $(x=2.30)$. The time that the participants spend on the Internet is analyzed one-way analysis of variance. As a result of the variance analysis, it is seen that for the $3^{\text {rd }}$ factor ("Reasons for Distance Education") $(\mathrm{F}=4,022 ; 01)$, the $4^{\text {th }}$ factor (The Effect of Distance Education on the Student) $(\mathrm{F}=3,220 ; 05)$ and $5^{\text {th }}$ factor (Advantages of Formal Education for Students) $(\mathrm{F}=4,082 ; 0)$, there are significant differences for the time spent on the internet. In order to test the source of the difference, it is necessary to employ Tukey test for the 3rd and 4th factors, and Tamhane's T2 test for 5th factor as explained before.

Table 11. Multiple Comparison Table: Tamhane's T2 Test for the 5th Factor

\begin{tabular}{|c|c|c|c|c|c|c|}
\hline \multicolumn{7}{|l|}{$\begin{array}{l}\text { Tamhane } \\
5^{\text {th }} \text { FACTOR AVERAGE }\end{array}$} \\
\hline \multirow{2}{*}{$\begin{array}{l}\text { (I) } \\
\text { Daily int. use }\end{array}$} & \multirow{2}{*}{$\begin{array}{l}\text { (J) } \\
\text { daily int. use }\end{array}$} & \multirow[b]{2}{*}{$\begin{array}{l}\text { Difference } \\
\text { Means (I-J) }\end{array}$} & \multirow[b]{2}{*}{$\begin{array}{r}\text { ofStandard } \\
\text { deviation }\end{array}$} & \multirow[b]{2}{*}{ Sig. } & \multicolumn{2}{|c|}{$\% 95$ confidence interval } \\
\hline & & & & & $\begin{array}{l}\text { Lower } \\
\text { limit }\end{array}$ & $\begin{array}{l}\text { Upper } \\
\text { limit }\end{array}$ \\
\hline \multirow[t]{4}{*}{ 0-1 hour } & $1-2$ hours & ,0476974 & ,2106691 & 1,000 &,- 562006 & 657400 \\
\hline & 2-3 hours & 0860340 & 2255188 & 1,000 &,- 571963 & 744031 \\
\hline & 3-4 hours &,- 3774038 & , 1816426 & ,361 &,- 913713 & ,158906 \\
\hline & 5 hours and more & 8687500 & ,3710815 & 309 &,- 385142 & 2,122642 \\
\hline \multirow[t]{4}{*}{$1-2$ hours } & $0-1$ hour &,- 0476974 & ,2106691 & 1,000 &,- 657400 &, 562006 \\
\hline & $2-3$ hours & ,0383366 & ,2257173 & 1,000 &,- 618719 & ,695392 \\
\hline & 3-4 hours &,- 4251012 & 1818891 & ,213 &,- 959210 & 109008 \\
\hline & 5 hours and more & ,8210526 & ,3712022 & ,375 &,- 432505 & 2,074610 \\
\hline \multirow[t]{4}{*}{$2-3$ hours } & 0-1 hour &,- 0860340 & 2255188 & 1,000 &,- 744031 &, 571963 \\
\hline & $1-2$ hours &,- 0383366 & 2257173 & 1,000 &,- 695392 & 618719 \\
\hline & 3-4 hours &,- 4634378 & 1988993 & ,226 & $-1,054771$ & 127896 \\
\hline & 5 hours and more & ,7827160 & ,3798267 & 454 &,- 480470 & 2,045903 \\
\hline \multirow[t]{4}{*}{ 3-4 hours } & $0-1$ hour & ,3774038 & , 1816426 & ,361 &,- 158906 & ,913713 \\
\hline & 1-2 hours & 4251012 & 1818891 & ,213 &,- 109008 & 959210 \\
\hline & $2-3$ hours & ,4634378 & 1988993 & ,226 &,- 127896 & 1,054771 \\
\hline & 5 hours and more & 1,2461538 & ,3555330 &, 050 &,- 000673 & 2,492981 \\
\hline \multirow[t]{4}{*}{5 hours and more } & $0-1$ hour &,- 8687500 & ,3710815 & ,309 & $-2,122642$ & 385142 \\
\hline & 1-2 hours &,- 8210526 & ,3712022 & ,375 & $-2,074610$ & ,432505 \\
\hline & $2-3$ hours &,- 7827160 & ,3798267 &, 454 & $-2,045903$ & ,480470 \\
\hline & 3-4 hours & $-1,2461538$ & ,3555330 &, 050 & $-2,492981$ & ,000673 \\
\hline
\end{tabular}

As it is seen in Table 11, it has been concluded that there is no significant difference between the averages of the pairs. 
Table 12. Multiple Comparison Table Tukey Test for 3rd Factors

\begin{tabular}{|c|c|c|c|c|c|c|}
\hline \multicolumn{7}{|c|}{$\begin{array}{l}\text { 3rd FACTOR AVERAGE } \\
\text { Tukey HSD } \\
\end{array}$} \\
\hline \multirow{2}{*}{$\begin{array}{l}\text { (I) } \\
\text { daily int. use }\end{array}$} & \multirow{2}{*}{$\begin{array}{l}\text { (J) } \\
\text { daily int. use }\end{array}$} & \multicolumn{2}{|c|}{ Difference ofStandard } & \multicolumn{3}{|c|}{$\% 95$ confidence interval } \\
\hline & & Means (I-J) & Deviation & & Lower 1 & Upper limit \\
\hline \multirow[t]{4}{*}{ 0-1 hour } & $1-2$ hours &,- 39803 & 21488 & ,349 &,- 9936 & 1975 \\
\hline & $2-3$ hours & ,37731 & 23403 & ,493 &,- 2713 & 1,0259 \\
\hline & 3-4 hours &,- 18750 & 29456 & ,969 & $-1,0039$ & 6289 \\
\hline & 5 hours and more &, 51250 & ,32446 & ,513 &,- 3867 & 1,4117 \\
\hline \multirow[t]{4}{*}{ 1-2 hours } & $0-1$ hour & 39803 & 21488 & ,349 &,- 1975 & ,9936 \\
\hline & 2-3 hours & ,77534* & 22542 & ,007 & ,1506 & 1,4001 \\
\hline & 3-4 hours & 21053 & 28776 & ,949 &,- 5870 & 1,0081 \\
\hline & 5 hours and more & ,91053* & ,31830 & ,039 & ,0283 & 1,7927 \\
\hline \multirow[t]{4}{*}{ 2-3 hours } & $0-1$ hour &,- 37731 & 23403 & ,493 & $-1,0259$ & 2713 \\
\hline & 1-2 hours &,$- 77534^{*}$ & 22542 & ,007 & $-1,4001$ &,- 1506 \\
\hline & 3-4 hours &,- 56481 & ,30233 & ,340 & $-1,4027$ & ,2731 \\
\hline & 5 hours and more & 13519 & 33154 & ,994 &,- 7837 & 1,0540 \\
\hline \multirow[t]{4}{*}{ 3-4 hours } & $0-1$ hour & 18750 & 29456 & ,969 &,- 6289 & 1,0039 \\
\hline & $1-2$ hours &,- 21053 & 28776 & ,949 & $-1,0081$ & ,5870 \\
\hline & 2-3 hours & ,56481 & 30233 & ,340 &,- 2731 & 1,4027 \\
\hline & 5 hours and more & 70000 & ,37671 & ,346 &,- 3441 & 1,7441 \\
\hline \multirow{4}{*}{$\begin{array}{l}5 \text { hours and } \\
\text { more }\end{array}$} & $0-1$ hour &,- 51250 & ,32446 & ,513 & $-1,4117$ & ,3867 \\
\hline & $1-2$ hours &,$- 91053^{*}$ & , 31830 & ,039 & $-1,7927$ &,- 0283 \\
\hline & 2-3 hours &,- 13519 & 33154 & ,994 & $-1,0540$ & 7837 \\
\hline & 3-4 hours &,- 70000 & ,37671 & ,346 & $-1,7441$ & ,3441 \\
\hline
\end{tabular}

According to Table 12, it is observed that there is a significant relationship between the participants who use the internet for 1-2 hours per day and the participants who have 2-3 hours. At the same time, it is shown that the participants who spend 1-2 hours and 5 or more hours have a highly significant relationship for the $3^{\text {rd }}$ factor named as "Reasons for Distance Education".

According to Table 13, when the groups, which are the 4th factor and indicate the effect of distance education on students, are examined, it is observed that there is a significant relationship between the participants who have daily internet usage for 1-2 hours per a day and those who spent 5 hours or more.

Table 13. Multiple Comparison Table Tukey Test for 4th Factors 


\begin{tabular}{|c|c|c|c|c|c|c|}
\hline \multicolumn{7}{|c|}{$\begin{array}{l}\text { 4th FACTOR AVERAGE } \\
\text { Tukey HSD }\end{array}$} \\
\hline \multirow{2}{*}{$\begin{array}{l}\text { (I) } \\
\text { Daily int. use }\end{array}$} & \multirow{2}{*}{$\begin{array}{l}\text { (J) } \\
\text { Daily int. use }\end{array}$} & \multicolumn{3}{|c|}{ Difference ofStandard } & \multicolumn{2}{|c|}{$\% 95$ confidence interval } \\
\hline & & Means (I-J) & Deviation & Sig. & Lower & Upper limit \\
\hline \multirow[t]{4}{*}{$0-1$ hour } & 1-2 hours & ,322 & ,276 & 769 &,- 44 & 1,09 \\
\hline & 2-3 hours &, 060 & ,300 & 1,000 &,- 77 & 89 \\
\hline & 3-4 hours &,- 587 & ,378 &, 531 & $-1,63$ & ,46 \\
\hline & 5 hours and more &,- 925 & ,416 & 179 & $-2,08$ & ,23 \\
\hline \multirow[t]{4}{*}{ 1-2 hours } & 0-1 hour &,- 322 & ,276 & 769 & $-1,09$ & 44 \\
\hline & 2-3 hours &,- 262 & ,289 & 894 & $-1,06$ &, 54 \\
\hline & 3-4 hours &,- 909 & ,369 & 107 & $-1,93$ & 11 \\
\hline & 5 hours and more & $-1,247^{*}$ & ,408 & 023 & $-2,38$ &,- 12 \\
\hline \multirow[t]{4}{*}{ 2-3 hours } & 0-1 hour &,- 060 & ,300 & 1,000 &,- 89 & ,77 \\
\hline & $1-2$ hours & 262 & ,289 & ,894 &,- 54 & 1,06 \\
\hline & 3-4 hours &,- 647 & ,388 & ,458 & $-1,72$ & ,43 \\
\hline & 5 hours and more &,- 985 & ,425 & 147 & $-2,16$ & 19 \\
\hline \multirow[t]{4}{*}{ 3-4 hours } & $0-1$ hour &, 587 & ,378 & ,531 &,- 46 & 1,63 \\
\hline & 1-2 hours & 909 & ,369 & 107 &,- 11 & 1,93 \\
\hline & 2-3 hours & 647 & ,388 & ,458 &,- 43 & 1,72 \\
\hline & 5 hours and more &,- 338 & ,483 & ,956 & $-1,68$ & 1,00 \\
\hline \multirow{4}{*}{$\begin{array}{l}5 \text { hours and } \\
\text { more }\end{array}$} & 0-1 hour & ,925 & ,416 & 179 &,- 23 & 2,08 \\
\hline & 1-2 hours & $1,247^{*}$ & ,408 & 023 & 12 & 2,38 \\
\hline & 2-3 hours & ,985 & ,425 & 147 &,- 19 & 2,16 \\
\hline & 3-4 hours & ,338 & ,483 & ,956 & $-1,00$ & 1,68 \\
\hline
\end{tabular}

\section{Conclusion and Discussion}

In this study, it is aimed to develop a scale for determining the factors that will affect students' choice of formal education and distance education in secondary education. To do so, two-part study conducted. In the first part the scale development process is followed. Based on the literature review, the item pool was created, then the item arrangements were made in line with the expert opinion and the scale was made ready for use respectively.

Moreover, the factors obtained as a result of this study also have some similarities with the literature. For example, Boydak (2001) tried to determine the effective learning style for students in his study named "Students' Learning Styles Identification List". Fidancioğlu (2018) focused on the factors affecting formal education. Kıvanç (2016) tried to determine what the factors and elements that affect students' university preferences are in his survey of "What Are the Elements Considered Important When Choosing Foundation Universities?" While Daban (2012) and Özbudun (2010) stated 
the advantages and disadvantages in a way to cover the general types of education, in this study, it is investigated deeper by also focusing on formal and distance education advantages and disadvantages for students. It is thought that the developed scale will be helpful in terms of the regulations to be made in the field of education both now and in the future, and it will be a guide in terms of future studies.

In the second part of the study, the scale was conducted and the collected data were analyzed. Accordingly, it was concluded that there was no significant difference for the school type variable in terms of students' preference for formal education and distance education. This situation is thought to come from the orientation activities in high schools. However, in the study of Daban (2012), it was concluded that there were high differences between the type of program studied by university students and their preference for distance education. It is thought that there may be differences due to the fact that Daban's study is aimed at university students, the sample audience appeals to the more mature population, and the study is applied to more participants.

It was concluded that there is a significant difference between the students' preference for formal education and distance education and the type of time they spend on the internet. It is seen that those who spend 2-3 hours a day on the internet prefer distance education more than those who spend 1-2 hours. At the same time, it is seen that those who spend 5 or more hours a day on the internet prefer distance education more than those who spend 1-2 hours. In other words, it can be concluded that the effect of distance education on students is greater in those who spend 5 or more hours a day on the Internet than those who spend 1-2 hours. As Köksal (2015) stated, young people born after the 2000s and growing up with technological tools are fond of the internet. It has been concluded that young people who spend more time on the internet prefer distance education more and that distance education is more effective for these students. According to Kaya et al. (2019), adolescents' tendency to engage in risky behavior increases as the time they spend daily on the internet increases. Adolescents should be kept under control by families and educators at certain times and studies on internet addiction should be organized.

With the development of technology, continuing distance education activities regardless of time and location eliminates physical barriers in access- 
ing information. Formal education activities may not be accessible to everyone due to time and location limitations. It is thought that the implementation of both educational activities in educational environments in the light of technological developments, carrying out such studies will help the digitalization of education by increasing the quality and efficiency of education in cooperation with students, teachers and families.

\section{Suggestions}

As a limitation, this study is carried out only one metropolitan city. However, in order to increase generalizability of those interesting results, such studies can be repeated in metropolitan city such as İstanbul, Ankara and so on by taking into account the cultural differences. Moreover, in order to increase the reliability and validity of the developed scale, more participants can be included and more sophisticated discussion were made on the results. Nevertheless, in order to understand the students' attitudes towards formal and distance education, this scale can be conducted to previous class students. In addition to students, preference of parents on formal and distance education may be considered to deeper understand of this results. In this study, time spent on the Internet have been considered, but time spent on the social media and social media supported education are worth to investigate in terms of students' preferences on education types.

\section{References}

Ağır, F. (2007). Özel okullarda ve devlet okullarında çalışan ilköğretim öğretmenlerinin uzaktan eğitime karşı tutumlarının belirlenmesi. (Yayımlanmamış yüksek lisans tezi). Balıkesir Üniversitesi, Balıkesir.

Ateş, E. (2019). Lise öğrencilerinin yaşam doyumlarm belirlemeye yönelik ölçek geliştirme çalı̧ması. (Yayımlanmamış yüksek lisans tezi). Ufuk Üniversitesi, Ankara.

Baturay, M. and Bay, Ö. F. (2009). Uzaktan öğretimi tercih eden öğrencilerin demografik özellikleri. Dicle Üniversitesi Ziya Gökalp Ĕ̆itim Fakültesi Dergisi, 13, 17-26.

Bayram, N. (2004). Sosyal Bilimlerde SPSS ile veri analizi. Bursa: 4 Nokta Matbaacılık Ltd. Şti.

Boydak, A. (2001). Öğrenme Stilleri. Beyaz Yayınları: İstanbul. 
Büyüköztürk, Ş. (2005). Anket geliştirme. Türk Eğitim Bilimleri Dergisi, 3(2), 133151.

Büyüköztürk, Ş. (2014). Sosyal Bilimler İçin Veri Analizi El Kitabı.(19.bs) Ankara: Pegem Akademi.

Daban, Osman. (2012). Uzaktan eğitim öğrencilerinin sosyo-ekonomik özellikleri ve istihdam beklentileri: Süleyman Demirel Üniversitesi örneği. (Yayımlanmamış yüksek lisans tezi). Süleyman Demirel Üniversitesi, Isparta.

Fidancıoğlu, D. (2018). Vakıf üniversitesi öğrencilerinin üniversite tercihlerinde etkili olan faktörler: Sağllk Hizmetleri Meslek Yüksekokulları örneği. (Yayımlanmamış yüksek lisans tezi). KTO Karatay Üniversitesi, Konya.

Galusha, J.M. (1998). Barriers to Learning in Distance Education. Education Resources Information Center (ERIC). 10 Temmuz 2021 tarihinde https://eric.ed.gov/?id=ED416377 erişildi.

Gülbahar, Y. (2009). E-öğrenme. Ankara: Pegem Akademi Yayıncllk.

Hutcheson, G. and Sofroniou, N. (1999). The multivariate social scientist: Introductory statistics using generalized linear models. Thousand Oaks, CA: Sage Publications.

Kalaycı, Ş. (2014). SPSS Uygulamalı Çok Değişkenli İstatistik Teknikleri. (6.bs) Ankara: Asil Yayın Dağıtım Ltd.Şti.

Karaman, G. (2015). Canlı ders etkileşim düzeyi belirleme ölçeğinin geliştirilmesi ve otomatik kestirim sisteminin tasarlanması. (Yayımlanmamış doktora tezi). Atatürk Üniversitesi, Erzurum.

Kaya, Z., Bedir, G. and Kaval, A. (2019). Lise öğrencilerinde riskli davranışlar ve oyun bağımlılığının incelenmesi. EJERCONGRESS 2019 Conference proceedings, (1358-1372). 10 Teтmuz 2021 tarihinde https://www.researchgate.net/publication/338826050_Lise_Ogrencilerinde_Ri skli_Davranislar_ve_Oyun_Bagimliliginin_Incelenmesi_Investigation_of_Ris ky_Behaviors_and_Game_Addiction_in_High_School_Students adresinden erişildi.

Kıvanç, K. (2016). Vakıf üniversitelerinde halkla ilişkiler faaliyetlerinin öğrencilerin üniversite tercihleri üzerindeki etkisi üzerine bir araştırma. (Yayımlanmamış yüksek lisans tezi). Nişantaşı Üniversitesi, İstanbul.

Köksal, Y., (2015). İnternet bağımlılığı ile internetten alışveriş ilişkisi üzerine bir incelenme; üniversite öğrencileri uygulaması. Mehmet Akif Ersoy Üniversitesi Sosyal Bilimler Enstitüsü Dergisi, 7(12), 117-130. 
Muilenburg, L. and Berge, Z.L. (2001). Barriers to distance education: A factoranalytic study. The American Journal of Distance Education, 15(2), 7-22. https://doi.org/10.1080/08923640109527081

Özbudun, F. (2010). Web tabanl uzaktan eğitimin mesleki ve teknik eğitimde kullanımı üzeinde bir araştırma.(Yayımlanmamış yüksek lisans tezi). Gazi Üniversitesi, Ankara.

Street, H. (2010). Factors Influencing a Learner's Decision to Drop-Out or Persist in Higher Education Distance Learning, Online Journal of Distance Learning Administration, University of West Georgia, Distance Education Center, Volume XIII. 10 Temmuz 2021 tarihinde https://www.westga.edu/ distancelojdla/winter134/street134.html erişildi.

Tabachnick, B.G. and Fidell, L.S. (2013). Using Multivariate Statistics (Sixth ed.) Pearson, Boston.

Uslu, N. (2018). Ortaokul öğrencilerinin kavramsal öğrenmede zihinsel durumlarmmn belirlenmesi: Ölçek geliştirme çalışması. (Yayımlanmamış yüksek lisans tezi). Balıkesir Üniversitesi, Balıkesir.

Yürekli, E.(2018). Eğitim Hizmetleri Pazarlama Çabalarmm Üniversite Tercihleri Üzerine Etkisi. (Yayımlanmamış yüksek lisans tezi). Anadolu Üniversitesi, Eskişehir. 


\section{APPENDIX 1. \\ DETERMINING THE ATTITUDES OF SECONDARY SCHOOL STU- DENTS THAT WILL AFFECT THEIR CHOICES FOR FORMAL EDUCA- TION AND DISTANCE EDUCATION}

\begin{tabular}{|c|c|}
\hline \\
\hline \multicolumn{2}{|c|}{$\begin{array}{l}\text { Dear Participant, } \\
\text { This study was prepared in order to determine which educational activity students at sec- } \\
\text { ondary education level (Anatolian High School, Science High School and Vocational High } \\
\text { School) will choose in line with their attitudes and opinions about formal education and } \\
\text { distance education. The answers you have given to the questions will guide the studies to be } \\
\text { prepared in this direction. Your personal information will be kept confidential. We hope you } \\
\text { will answer the questions objectively. Thank you for your participation. Check only one } \\
\text { option. Please indicate the appropriate option you will mark with the (X) mark. } \\
\begin{array}{lll}\text { 1.Gender } & \text { () Female }\end{array}\end{array}$} \\
\hline \multicolumn{2}{|r|}{$\begin{array}{l}\text { ( ) Anatolian High School ( ) Science High School } \\
\text { ( ) Vocational high School }\end{array}$} \\
\hline 3. Branch & $\begin{array}{l}\text { ( ) Turkish- Mathematics } \quad \text { ( ) Natural Sciences ( ) } \\
\text { Social Sciences } \quad \text { ( ) other................. }\end{array}$ \\
\hline $\begin{array}{l}\text { 4. What is your mother's education } \\
\text { level? }\end{array}$ & $\begin{array}{l}\text { ( ) Primary ( ) Secondary ( ) Highschool } \\
\text { ( ) Associate degree ( )Undergraduate } \\
\text { ( ) Graduate }\end{array}$ \\
\hline $\begin{array}{l}\text { 5. What is your father's education } \\
\text { level? }\end{array}$ & $\begin{array}{l}\text { ( ) Primary ( ) Secondary ( ) Highschool } \\
\text { ( ) Associate degree ( )Undergraduate } \\
\text { ( ) Graduate }\end{array}$ \\
\hline $\begin{array}{l}\text { 6. Please indicate your family's month- } \\
\text { ly income? }\end{array}$ & $\begin{array}{l}\text { ( ) } 3001-4000 \mathrm{TL} \text { ( ) } 4001-5000 \mathrm{TL} \\
\text { ( ) } 5001 \mathrm{TL} \text { and above }\end{array}$ \\
\hline $\begin{array}{l}\text { 7. Which way do you prefer to study in } \\
\text { higher education? }\end{array}$ & ( ) Distance Education ( ) Formal Education \\
\hline $\begin{array}{l}\text { 8. Have you taken any distance educa- } \\
\text { tion lessons before? }\end{array}$ & ( ) Yes \\
\hline $\begin{array}{l}\text { 9. Where do you usually get internet } \\
\text { connection in distance education? }\end{array}$ & $\begin{array}{l}\text { ( )Home ( ) Work ( ) Internet Cafe ( ) } \\
\text { Device ( ) other ................. }\end{array}$ \\
\hline $\begin{array}{l}\text { 10. Which technological devices do } \\
\text { you prefer to use in distance educa- } \\
\text { tion? }\end{array}$ & ( ) Computer ( ) Mobile ( ) Teleconference \\
\hline $\begin{array}{l}\text { 11. How many hours do you spend } \\
\text { daily on the internet? }\end{array}$ & \\
\hline $\begin{array}{l}\text { 12. In which application do you spend } \\
\text { more time while using social media? }\end{array}$ & \\
\hline 13. Do you have a personal computer? & \\
\hline
\end{tabular}


Dear Participant,

You are expected to answer the following questions, which were created using the 5-point Likert Scale: 1 Strongly Disagree, 2 Disagree, 3 Undecided, 4 Agree, 5 Strongly Agree.

\begin{tabular}{|c|c|c|c|c|c|}
\hline FORMAL EDUCATION & & & & & \\
\hline The Effect of Formal Education on Students & 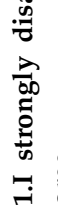 & 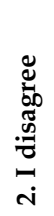 & 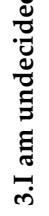 & 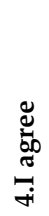 & 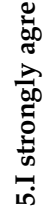 \\
\hline $\begin{array}{l}\text { 1. Practical lessons are taught more effectively in formal edu- } \\
\text { cation. }\end{array}$ & & & & & \\
\hline 2. Formal education allows students to socialize. & & & & & \\
\hline $\begin{array}{l}\text { 3. Group work in classroom activities ensures effective learn- } \\
\text { ing. }\end{array}$ & & & & & \\
\hline 4. At school, more is learned than what is learned at home. & & & & & \\
\hline $\begin{array}{l}\text { 5. Scholarships and internship opportunities are offered to } \\
\text { students in formal education. }\end{array}$ & & & & & \\
\hline $\begin{array}{l}\text { 6. The influence of the teacher in formal education is greater } \\
\text { than that of distance education. }\end{array}$ & & & & & \\
\hline 7. Face to face interaction is much in formal education. & & & & & \\
\hline $\begin{array}{l}\text { 8. Spending my student period in a different city may lead me } \\
\text { to prefer formal education. }\end{array}$ & & & & & \\
\hline Reasons for Choosing Formal Education & & & & & \\
\hline $\begin{array}{l}\text { 9. The food facilities provided by the school are important to } \\
\text { me. }\end{array}$ & & & & & \\
\hline $\begin{array}{l}\text { 10. Schools have spring festivals, which is the reason I prefer } \\
\text { formal education. }\end{array}$ & & & & & \\
\hline $\begin{array}{l}\text { 11. It is important to use laboratory materials in order to } \\
\text { prefer formal education. }\end{array}$ & & & & & \\
\hline $\begin{array}{l}\text { 12. I prefer formal education because I want to study in a } \\
\text { department that is not included in distance education. }\end{array}$ & & & & & \\
\hline Advantages of Formal Education for Students & & & & & \\
\hline $\begin{array}{l}\text { 13. I would like to learn about other students' success in ex- } \\
\text { ams. }\end{array}$ & & & & & \\
\hline 14. Students sitting in the front row are more successful. & & & & & \\
\hline 15. Homework control affects learning. & & & & & \\
\hline $\begin{array}{l}\text { 16. I write down every word that comes out of the teacher's } \\
\text { mouth. }\end{array}$ & & & & & \\
\hline Students' Preparation for Exams & & & & & \\
\hline 17. I work enough to pass lessons. & & & & & \\
\hline
\end{tabular}




\begin{tabular}{|c|c|c|c|c|c|}
\hline \multirow[t]{2}{*}{ DISTANCE EDUCATION } & \multirow{3}{*}{ 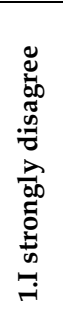 } & \multirow{3}{*}{ 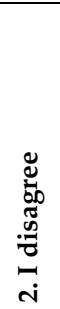 } & \multirow{3}{*}{ 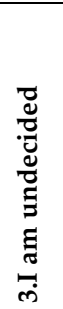 } & \multirow[b]{3}{*}{ 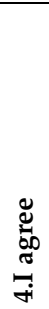 } & \multirow{3}{*}{ 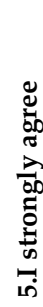 } \\
\hline & & & & & \\
\hline The Effect of Distance Education on Students & & & & & \\
\hline \multicolumn{6}{|l|}{$\begin{array}{l}\text { 19. According to distance education, the low number of stu- } \\
\text { dents in formal education reduces the problems in communi- } \\
\text { cation. }\end{array}$} \\
\hline \multicolumn{6}{|l|}{$\begin{array}{l}\text { 20. Giving some courses in formal education prevents prob- } \\
\text { lems in terms of practice. }\end{array}$} \\
\hline \multicolumn{6}{|l|}{$\begin{array}{l}\text { 21. When I choose distance education, this may lead me to } \\
\text { prefer formal education due to the insufficient attention of the } \\
\text { academic staff and the concern of inadequate technical sup- } \\
\text { port. }\end{array}$} \\
\hline \multicolumn{6}{|l|}{ Reasons to Choose Distance Education } \\
\hline \multicolumn{6}{|l|}{$\begin{array}{l}\text { 22. Older people prefer to benefit from distance education } \\
\text { activities. }\end{array}$} \\
\hline \multicolumn{6}{|l|}{$\begin{array}{l}\text { 23. People who have to work have the opportunity to com- } \\
\text { plete their learning process through distance education. }\end{array}$} \\
\hline \multicolumn{6}{|l|}{$\begin{array}{l}\text { 24. Distance education activities are suitable for those who } \\
\text { have time and space constraints. }\end{array}$} \\
\hline \multicolumn{6}{|l|}{$\begin{array}{l}\text { 25. Individuals having responsibilities for family care prefer } \\
\text { distance education }\end{array}$} \\
\hline \multicolumn{6}{|l|}{ Advantages of Distance Education for Students } \\
\hline \multicolumn{6}{|l|}{$\begin{array}{l}\text { 26. It is easy to meet the learning needs of disabled students } \\
\text { with distance education. }\end{array}$} \\
\hline \multicolumn{6}{|l|}{$\begin{array}{l}\text { 27. I can take lessons from famous academicians through } \\
\text { distance education. }\end{array}$} \\
\hline \multicolumn{6}{|l|}{$\begin{array}{l}\text { 28. Housewives generally participate in distance education } \\
\text { activities. }\end{array}$} \\
\hline \multicolumn{6}{|l|}{ Distance Education Perception of Students } \\
\hline \multicolumn{6}{|l|}{$\begin{array}{l}\text { 29. Writing distance education in the diploma in job applica- } \\
\text { tions prevents recruitment. }\end{array}$} \\
\hline $\begin{array}{l}\text { 30. A marriage situation in the future may lead me to prefer } \\
\text { distance education. }\end{array}$ & & & & & \\
\hline
\end{tabular}




\section{Citation Information}

Karaman, G., Bora, N. ve Seven, S. (2021). The scale for determining the factors affecting The Students' Choice of Formal and Distance Education in Secondary School. OPUS-International Journal of Society Research, 18(41), 3144-3171. DOI:10.26466//opus.970860. 